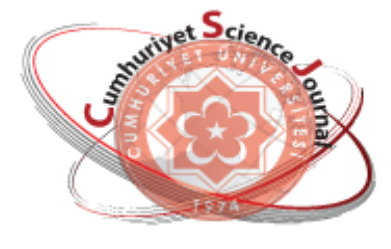

e-ISSN: $2587-246 X$

ISSN: $2587-2680$

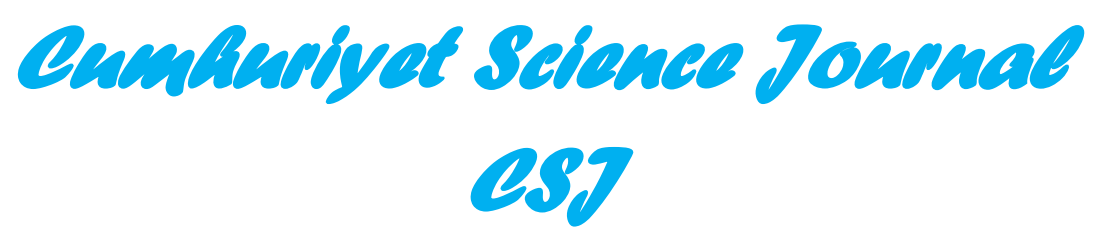

Cumhuriyet Sci. J., Vol.40-3 (2019) 602-611

\title{
Structural and Optical Properties of Indium Selenide (InSe) Thin Films Deposited on Glass and GaSe Single Crystal Substrates by SILAR Method
}

\author{
Hüseyin ERTAP ${ }^{I^{*}}$ (D), Mustafa YÜKSEK ${ }^{2}$ (D), Mevlüt KARABULUT ${ }^{3}$ \\ ${ }^{1}$ Department of Physics, Science and Letters Faculty, Kafkas University, 36100 Kars, Turkey \\ ${ }^{2}$ Department of Electrical-Electronics Engineering, Faculty of Engineering, Kafkas University, 36100 Kars, \\ Turkey \\ ${ }^{3}$ Department of Physics, Faculty of Science, Gebze Technical University, 41400 Kocaeli, Turkey
}

\begin{abstract}
Structural, morphological and optical properties of undoped and boron doped Indium Selenide (InSe) thin films grown on glass and layered Gallium Selenide $(\mathrm{GaSe})$ single crystal substrates with SILAR method have been investigated by XRD, AFM and UV-Vis spectrophotometer techniques. XRD measurements showed that the crystal structure of InSe thin films grown on glass substrates were hexagonal P61 $\gamma$ - $\operatorname{In}_{2} \mathrm{Se}_{3}$ with lattice parameters $\mathrm{a}=7.1286 \AA, \mathrm{c}=19.382 \AA$ and $\mathrm{z}=6$ while the InSe thin films grew as hexagonal P63 $/ \mathrm{mmc}$ InSe with lattice parameters $a=4.005 \AA, c=16.640 \AA$ and $z=4$ on GaSe single crystal substrates. The AFM images showed that average particle sizes of undoped and boron doped InSe thin films were found to be varying between 26.5$60.2 \mathrm{~nm}$ and 30.9-101.5 $\mathrm{nm}$ grown on glass and GaSe single crystal substrates, respectively. The optical absorption spectra of undoped and boron doped InSe thin films grown on both glass and GaSe single crystal substrates showed absorption maxima around the 2.00 and $2.24 \mathrm{eV}$, respectively. The calculated Urbach energies of the InSe thin films grown on glass substrates were found bigger than those of the InSe thin films grown on GaSe single crystal substrates.
\end{abstract}

Keywords: Indium Selenide, SILAR, thin film, GaSe single crystal substrate, Boron.

\section{SILAR Metodu ile Cam ve GaSe Tek Kristal Alt Tabanlar Üzerinde Büyütülen İndiyum Selenit (InSe) İnce Filmlerinin Yapısal ve Optik Özellikleri}

\begin{abstract}
Özet. SILAR metodu ile cam ve tabakalı Galyum Selenit (GaSe) tek kristal alt tabanlar üzerinde büyütülen saf ve bor katkılı İndiyum Selenit (InSe) ince filmlerinin yapısal, morfolojik ve optik özellikleri XRD, AFM ve UV-Vis spektrofotometre teknikleri ile araştırıldı. XRD ölçümlerinden cam alt tabanlar üzerinde büyütülen InSe ince filmlerinin örgü parametrelerinin $\mathrm{a}=7.1286 \AA$, $\mathrm{c}=19.382 \AA$ ve $\mathrm{z}=6$ olan hekzagonal P61 $\gamma$ - $\operatorname{In}_{2} \mathrm{Se}_{3}$ iken GaSe tek kristal alt tabanlar üzerinde büyütülen InSe ince filmlerinin örgü parametrelerinin a=4.005 $\AA, c=16.640 \AA$ ve $\mathrm{z}=4$ olan hekzagonal $\mathrm{P} 63 / \mathrm{mmc}$ InSe olduğu görüldü. AFM görüntülerinden cam ve GaSe tek kristal alt tabanlar üzerinde büyütülen saf ve bor katkılı InSe ince filmlerinin ortalama parçacık boyutlarının sırasıyla 26.5-60.2 $\mathrm{nm}$ ve 30.9-101.5 $\mathrm{nm}$ aralığında değiştiği bulundu. Hem cam hem de GaSe tek kristal alt tabanlar üzerinde büyütülen saf ve bor katkılı InSe ince filmlerinin optik soğurma spektrumlarında sirasıyla 2.00 ve $2.24 \mathrm{eV}$ civarında soğurma maksimumları gösterdi. Cam alt tabanlar üzerinde büyütülen InSe ince filmlerinin Urbach enerjilerinin GaSe tek kristal alt tabanlar üzerinde büyütülen InSe ince filmlerinin Urbach enerjilerinden daha büyük olduğu bulundu.
\end{abstract}

Anahtar Kelimeler: İndiyum Selenit, SILAR, ince film, GaSe tek kristal alt taban, Bor.

\footnotetext{
* Corresponding author. Email address: huseyinertap@gmail.com and huseyinertap@kafkas.edu.tr http://dergipark.gov.tr/csj $\quad$ (C)2016 Faculty of Science, Sivas Cumhuriyet University
} 


\section{INTRODUCTION}

Indium Selenide (InSe) is a member of $\mathrm{A}^{\mathrm{III}} \mathrm{B}^{\mathrm{VI}}$ layered semiconductor crystals family, which also includes Gallium Selenide (GaSe), Gallium Tellurit (GaTe) and Gallium Sulphide (GaS) semiconductor crystals. These layered semiconductor crystals have strong anisotropies in chemical bonds between and within the layers as the layers are bonded together by the weak van der Waals forces while within the layers strong covalent bonds dominate. Absence of dangling bonds on the cleaved surfaces makes these crystals appropriate for the formation of heterojunctions [1-8]. InSe crystallizes in the stacking type of layers, each monolayer consist of two indium and two selenium closed-packed sublayers in the stacking sequence of Se-In-In-Se along the c axis [3, 9]. InSe single crystal has a band gap around $1.3 \mathrm{eV}$ [9] and this property makes it desired material for solar cell applications [5, 10, 11]. Stoichiometric InSe is an n-type semiconductor, on the other hand, when it doped with any atoms the conductivity may change to p-type. There are four defined compounds in the phase diagram of In-Se denoted by $\operatorname{InSe}, \alpha-\operatorname{In}_{2} \mathrm{Se}_{3}, \alpha-\mathrm{In}_{3} \mathrm{Se}_{8}$ and $\operatorname{In}_{2} \mathrm{Se}$ [12]. InSe thin films have been studied for solar cell applications [5]. Nonlinear refraction index of InSe thin films deposited by thermal evaporation has been studied recently [13]. Deposition techniques, starting materials and preparation conditions are important because of the possibility of different phases for InSe thin films. In addition, deposition techniques may affect the structures, optical and electrical properties of thin films.

Several deposition techniques have been used in the growth of thin films. These methods include vacuum evaporation, microwave glow discharge, chemical vapor deposition, modulated flux deposition, Molecular Beam Epitaxy, Chemical Bath Deposition (CBD), electrodeposition, thermal evaporation and modified chemical bath deposition (M-CBD) [12-19]. The M-CBD method is also known as SILAR. SILAR method is a relatively simple and inexpensive method, however suitable for large area deposition of different configurations. The SILAR method is based on sequential reactions of cationic and anionic constituents at the substrate surface. It is a stepwise process of chemical deposition of thin films. Because of the Van der Waals bonds between the layers, the (0001) surfaces of the GaSe layers do not have dangling bonds. For this reason, InSe thin films grown on these substrates bind via Van der Waals bonds. Since the surface density of the states of naturally mirror faced GaSe layer is low (less than $10^{6} \mathrm{~cm}^{-2}$ ) [20], the density of states of heterojunctions formed by the InSe-GaSe junctions may have low density of states.

In the present study, as well known that the ion radii of the substituted atoms change the lattice parameters of the crystal structure and alter the band gaps of the crystals. For these reasons, we preferred the boron doping to InSe to investigate the changes in the lattice parameters and band gaps of the crystals. Undoped and boron doped InSe thin films have been prepared by the SILAR method on glass and GaSe single crystal substrates and their structural, morphological, optical properties were investigated by XRD, AFM and UV-Vis absorption measurements. 


\section{EXPERIMENTAL}

The GaSe single crystal substrates were cleaved from the GaSe single crystal ingots grown by Bridgman method $[6,21]$ by using a razor blade. The substrates were prepared at $1 \mathrm{cmx} 3 \mathrm{cmx} 80 \mu \mathrm{m}$ sizes. No chemical process was applied to these naturally mirror faced GaSe single crystals prior to growth process. In addition, InSe thin films were also grown on glass substrates. The glass substrates were cleaned thoroughly before the deposition process. In order to obtained In and Se source solutions, which are $\mathrm{In}_{2}\left(\mathrm{SO}_{4}\right)_{3}$ and $\mathrm{Na}_{2} \mathrm{SeSO}_{3}$, In particles and $\mathrm{Se}$ powders were dissolved in $\mathrm{H}_{2} \mathrm{SO}_{4}$ and $\mathrm{NaSO}_{3}$ solvents, respectively. The $\mathrm{Na}_{2} \mathrm{~B}_{4} \mathrm{O}_{7} \cdot 10 \mathrm{H}_{2} \mathrm{O}$ solution was added to the cationic solution for the deposition of boron doped InSe thin films. The $\mathrm{pH}$ of the solutions was fixed to $\sim 3$ by addition of tartaric acid to the solvents. Four glass beakers were named as 1, 2, 3 and 4. Then, $20 \mathrm{ml} \mathrm{In}_{2}\left(\mathrm{SO}_{4}\right)_{3}$ and $20 \mathrm{ml} \mathrm{Na}_{2} \mathrm{SeSO}_{3}$ were added to 1 and 3 glass beakers, respectively, and glass beakers which are named as 2 and 4 were filled with distilled water. The substrates were immersed vertically into the 1, 2, 3 and 4 glass beakers, respectively. The substrates were stood up into the 1,2, 3 and 4 glass beakers as $30 \mathrm{~s}, 70 \mathrm{~s}, 10 \mathrm{~s}$ and $70 \mathrm{~s}$, respectively, and each of this process named as a cycle. Cycles were carried out 75 and 50 times for the deposition of InSe thin films on the glass and the GaSe single crystal substrates, respectively. The thicknesses of InSe thin films were estimated by the amount of films deposited, the surface area and the density [22]. The thickness of InSe thin films grown on glass substrates were calculated as $\sim 110 \mathrm{~nm}$.

The surface morphology of undoped and boron doped InSe thin films grown on glass and GaSe single crystal substrates were studied with help of a PSIAXE-100E model Atomic Force Microscopy (AFM). The structures of the thin films were characterized by using a X-ray diffractometer (XRD) (Rigaku D/max-2200). The optical absorption spectra of the thin films were recorded with help of a UV-Vis spectrophotometer (Perkin-Elmer Lambda 25).

\section{RESULT AND DISCUSSION}

The XRD spectra of undoped and boron doped InSe thin films grown on glass substrates are given in Fig. $1 \mathrm{a}-\mathrm{b}$, respectively. 


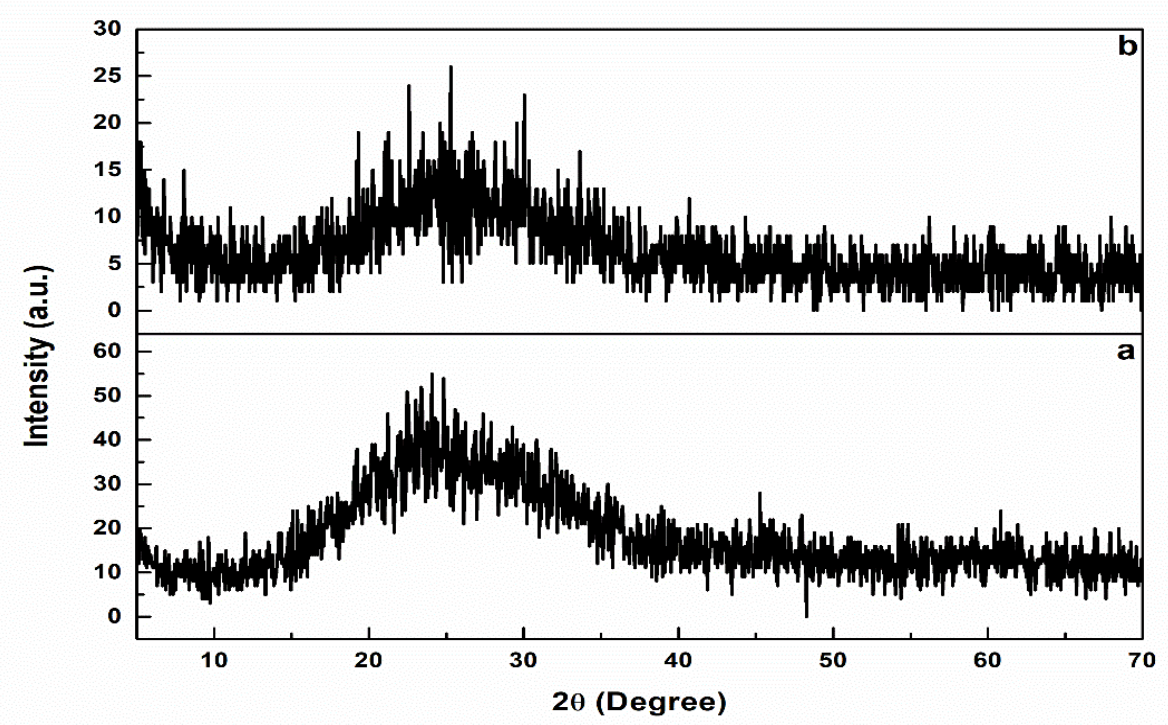

Figure 1. The XRD spectra of (a) undoped, (b) boron doped InSe thin films grown on glass substrates.

As seen from Fig. 1 a-b, undoped and boron doped InSe thin films grew in crystalline form on glass substrate. The structure of InSe thin films are determined as hexagonal $\left(\gamma-\operatorname{In}_{2} \mathrm{Se}_{3}\right)$ with a $=7.128 \AA$, $\mathrm{c}=19.382 \AA, \mathrm{z}=6$ lattice parameters and P61 space group (JCPDS Card No: 40-1407) [23]. The obtained crystallographic data is in accordance with the data given in the literature for $\operatorname{In}_{2} \mathrm{Se}_{3}$ crystal [23, 24]. The broad hump in the spectra of undoped and boron doped InSe thin films is due to the glass substrates. The XRD spectra values of undoped and boron doped InSe thin films, which are grown on glass substrates are found similar. The XRD spectra peaks of boron doped InSe thin films a little broad and the crystallization seems to be more prominent according to the undoped InSe thin films. It is clearly seen from the Fig. 1 a$\mathrm{b}$ that the peak intensities of the InSe thin films decrease with the boron addition. Peak positions of undoped and boron doped InSe thin films grown on glass substrates are given in Table 1 a-b, respevtively.

Table 1: Peak position of (a) undoped, (b) boron doped InSe thin films grown on glass substrates.

\begin{tabular}{|c|c|c|c|c|c|c|c|}
\hline \multirow[t]{2}{*}{ Thin Film } & \multicolumn{2}{|c|}{ 20(Degree) } & \multirow[t]{2}{*}{ Planes(hkl) } & \multirow[t]{2}{*}{ Thin Film } & \multicolumn{2}{|c|}{ 20(Degree) } & \multirow[t]{2}{*}{ Planes(hkl) } \\
\hline & Observed & PDF File & & & Observed & PDF File & \\
\hline & 23.249 & 23.338 & 104 & & 22.359 & 23.338 & 104 \\
\hline & 24.764 & 24.968 & 110 & & 24.704 & 24.968 & 110 \\
\hline & 25.437 & 25.377 & 111 & & 25.640 & 25.377 & 111 \\
\hline a) $\gamma-\operatorname{In}_{2} \mathrm{Se}_{3}$ & 29.430 & 29.274 & 201 & b) $\gamma-\operatorname{In}_{2} \mathrm{Se}_{3}$ & 29.546 & 29.274 & 201 \\
\hline JCPDS Card & 43.763 & 43.973 & 300 & JCPDS Card & 30.171 & 30.365 & 202 \\
\hline \multirow{7}{*}{ No: $40-1407$} & 45.353 & 45.337 & 215 & No: 40-1407 & 33.871 & 34.156 & 115 \\
\hline & 47.947 & 47.667 & 208 & & 35.653 & 35.504 & 107 \\
\hline & 59.304 & 59.137 & 226 & & 38.517 & 38.843 & 211 \\
\hline & & & & & 43.272 & 43.973 & 300 \\
\hline & & & & & 47.971 & 47.677 & 208 \\
\hline & & & & & 56.156 & 56.982 & 0012 \\
\hline & & & & & 59.653 & 59.137 & 226 \\
\hline
\end{tabular}

The XRD spectra of GaSe single crystal, undoped and boron doped InSe thin films grown on GaSe single crystal substrates are given in Fig. 2 a-c, respectively. Fig. 2 a is showing the XRD spectra of GaSe single 
crystal, grown by Bridgman method, which has a $=3.750 \AA, \mathrm{c}=15.950 \AA, \mathrm{z}=4$ lattice parameters and P63/mmc space group (JCPDS Card No: 37-0931) [25].

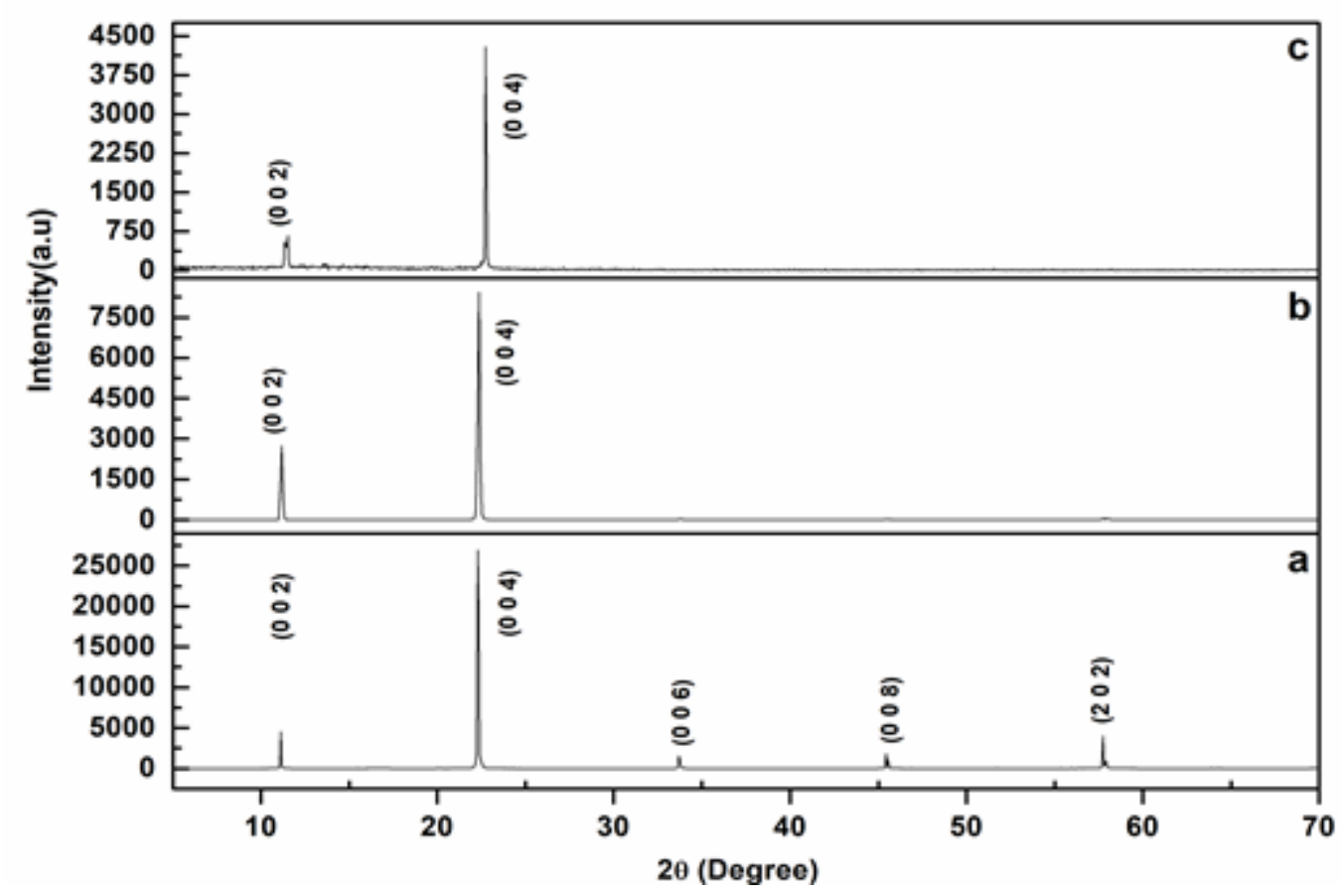

Figure 2. The XRD spectra of (a) GaSe single crystal substrate, (b) undoped, (c) boron doped InSe thin films grown on GaSe single crystal substrates.

X-ray diffraction analysis showed that peak intensities are decreasing and peak positions shifting to higher angles for undoped and boron doped InSe thin films compared to the GaSe single crystal substrate peaks. GaSe single crystal substrate has (l $\left.0 \begin{array}{lll}0 & 2\end{array}\right),\left(\begin{array}{lll}0 & 0 & 4\end{array}\right),\left(\begin{array}{lll}0 & 0 & 6\end{array}\right),\left(\begin{array}{lll}0 & 0 & 8\end{array}\right)$ and $\left(\begin{array}{lll}2 & 0 & 2\end{array}\right)$ difraction peaks (Fig. 2 a).

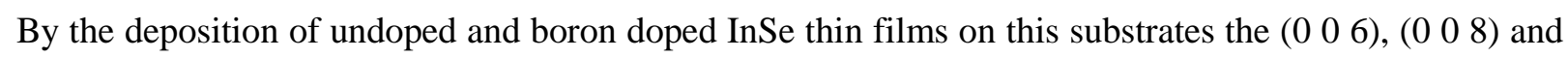
( $\left.\begin{array}{lll}2 & 0 & 2\end{array}\right)$ diffraction peaks quenched. There are some observable changes in the XRD spectra of both undoped and boron doped InSe thin films grown on GaSe single crystal substrates. Compared to the undoped InSe thin film, the XRD peak intensity of boron doped InSe thin film decrease and peak positions shift to higher degrees with boron addition. As a result, as noted before [12, 23, 24, 26-28], we have demonstrated that the thin film structures depend on the used substrate structures.

The surface morphology of undoped and boron doped InSe thin films grown on glass and GaSe single crystal substrates were investigated by AFM technique. The AFM images taken from different areas of undoped and boron doped InSe thin films grown on glass and GaSe single crystal substrates are given in Fig. 3 a-b and Fig. 4 a-b, respectively. 
a
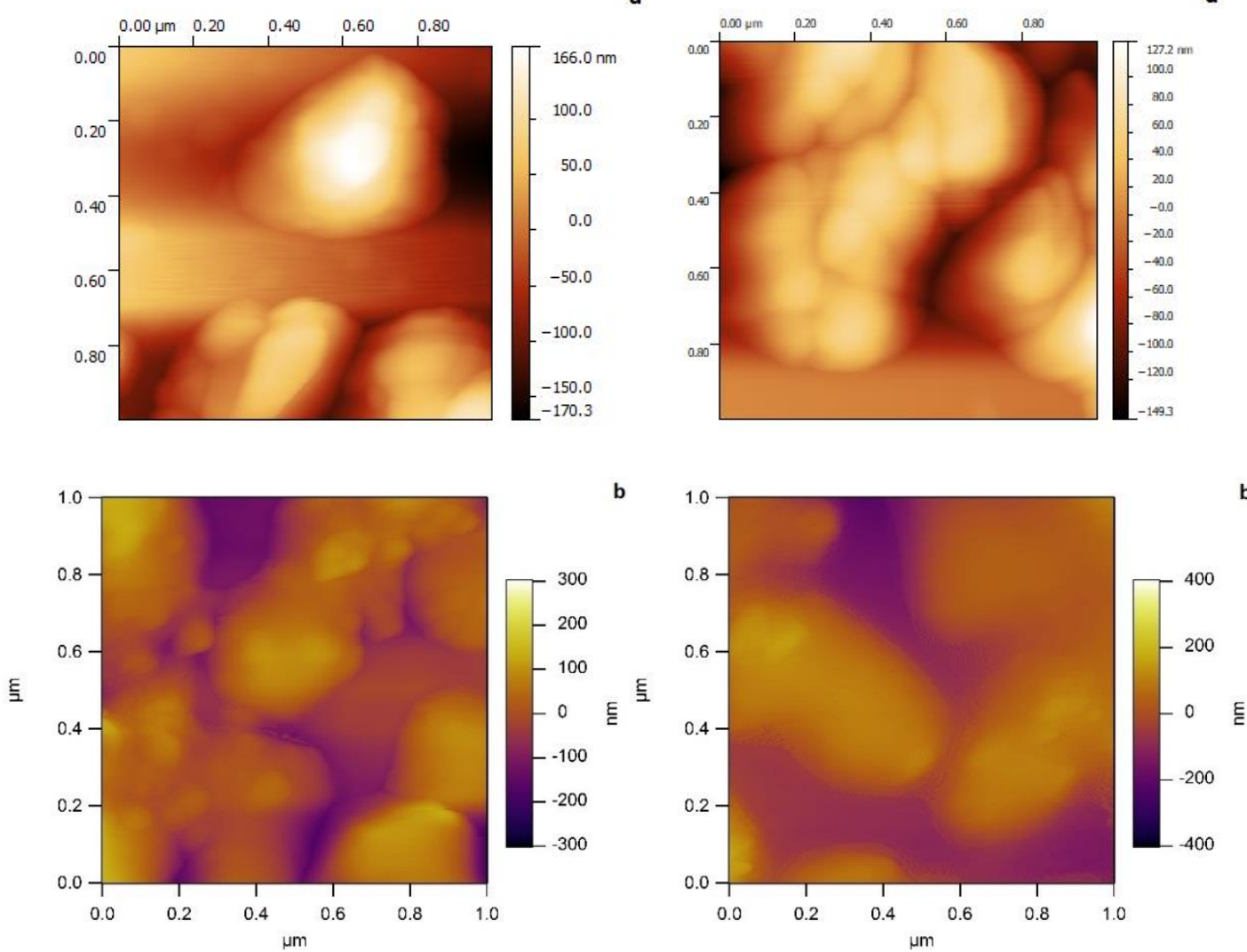

Figüre 3. The AFM images of (a) undoped, (b) boron doped InSe thin films grown on glass substrates in different areas.
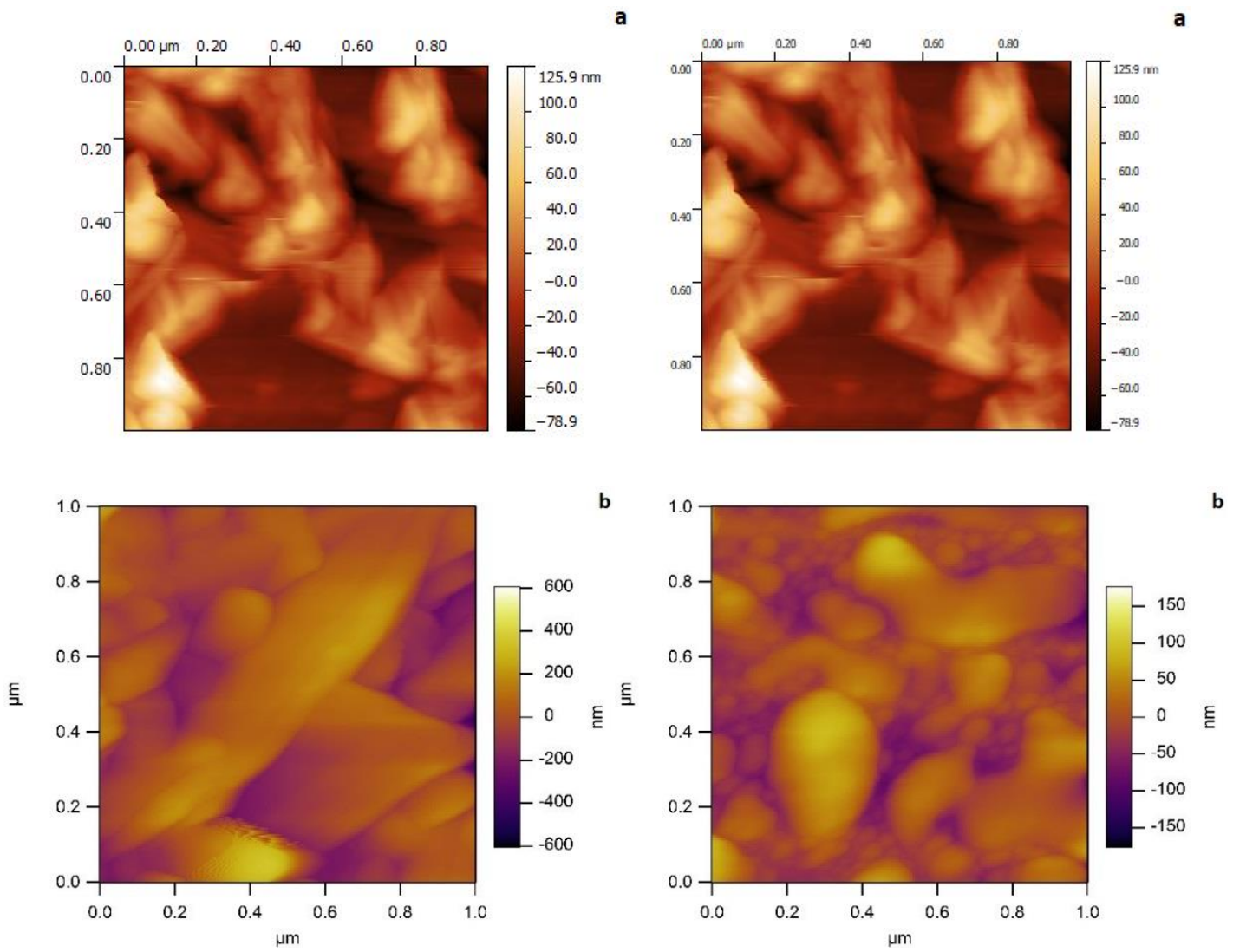

Figure 4. The AFM images of (a) undoped, (b) boron doped InSe thin films grown on GaSe single crystal substrates in different areas. 
The particle sizes of all thin films were determined from Fig. 3 and Fig. 4 images by using XEI 1.6.1 software. The obtained average particle sizes were estimated between 26.5-60.2 nm and 30.9-101.5 nm for undoped and boron doped InSe thin films deposited upon glass and GaSe single crystal substrates, respectively. Similar average particle sizes of the InSe thin film grown on glass substrate were found [16]. It is clearly seen from the estimated particle sizes that the average particle sizes of undoped and boron doped InSe thin films depend on substrate types. The effect of annealing on these thin films was studied previously and it was found that particle sizes increased as a result of the annealing [16].

The optical absorption spectra of undoped and boron doped InSe thin films grown on glass substrates are given in Figure $5 \mathrm{a}-\mathrm{b}$, respectively.
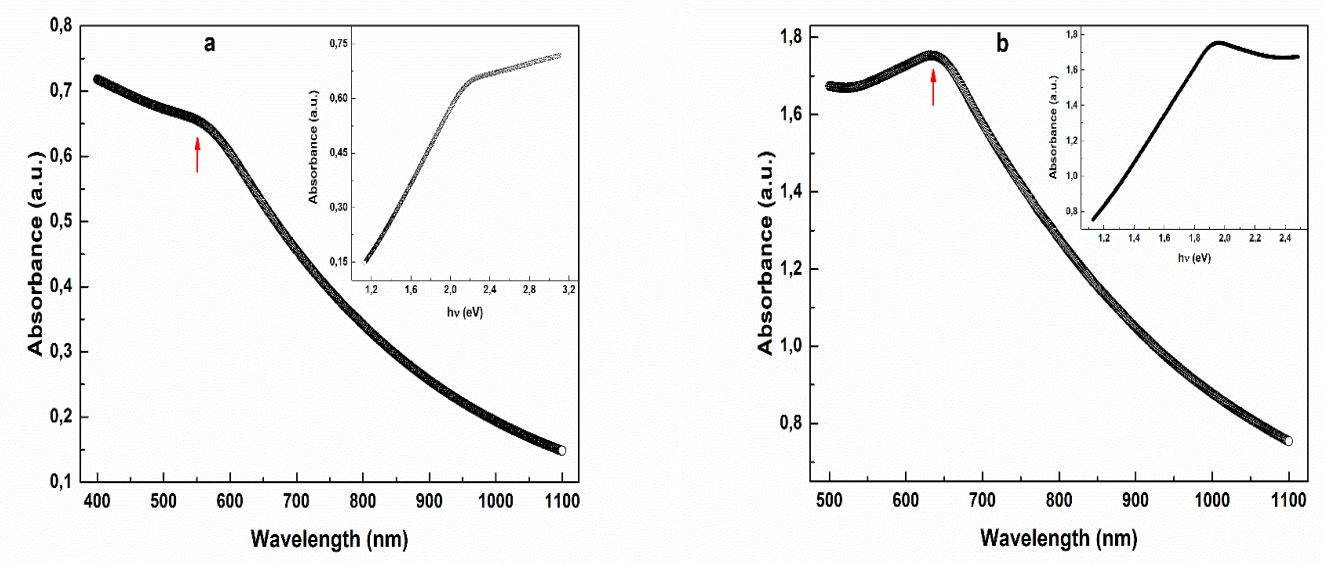

Figure 5. The optical absorption spectra of (a) undoped, (b) boron doped InSe thin films grown on glass substrates.

The slight increase at the absorption edge indicates the presence of the defect and dopant states at the band gap. The absorption tail of the InSe thin film grown on glass substrate starts at $1.13 \mathrm{eV}$. The absorption spectra of undoped InSe thin film have an exponential region, starting from $1.36 \mathrm{eV}$ and show a maximum at $2.24 \mathrm{eV}$. The absorption tail of boron doped InSe thin film is also starting from $1.13 \mathrm{eV}$, but the absorption maximum is ending at $1.96 \mathrm{eV}$. The absorption tail shows an exponential dependence on the energy according to the Urbach rule. Steepness of the exponential absorption tail is determined from the absorption spectra as:

$$
\alpha=\alpha_{0} \exp \left[\left(\frac{\sigma(T)}{k_{B} T}\right)\left(h \vartheta-E_{g}\right)\right]
$$

where $k_{B}$ is the Boltzman constant, $\mathrm{T}$ is the temperature and $v$ is the frequency of the incident photons. The Urbach energy is also determined with the steepness of the tail, $E_{u}=k_{B} T / \sigma$ [29-31]. The Urbach energies were calculated as $513 \mathrm{meV}$ and $792 \mathrm{meV}$ for undoped and boron doped InSe thin films grown on glass substrates, respectively. The optical absorption spectra of the GaSe single crystal substrate, undoped and boron doped InSe thin films grown on GaSe single crystal substrates are given in Figure 6 a-c, respectively. 

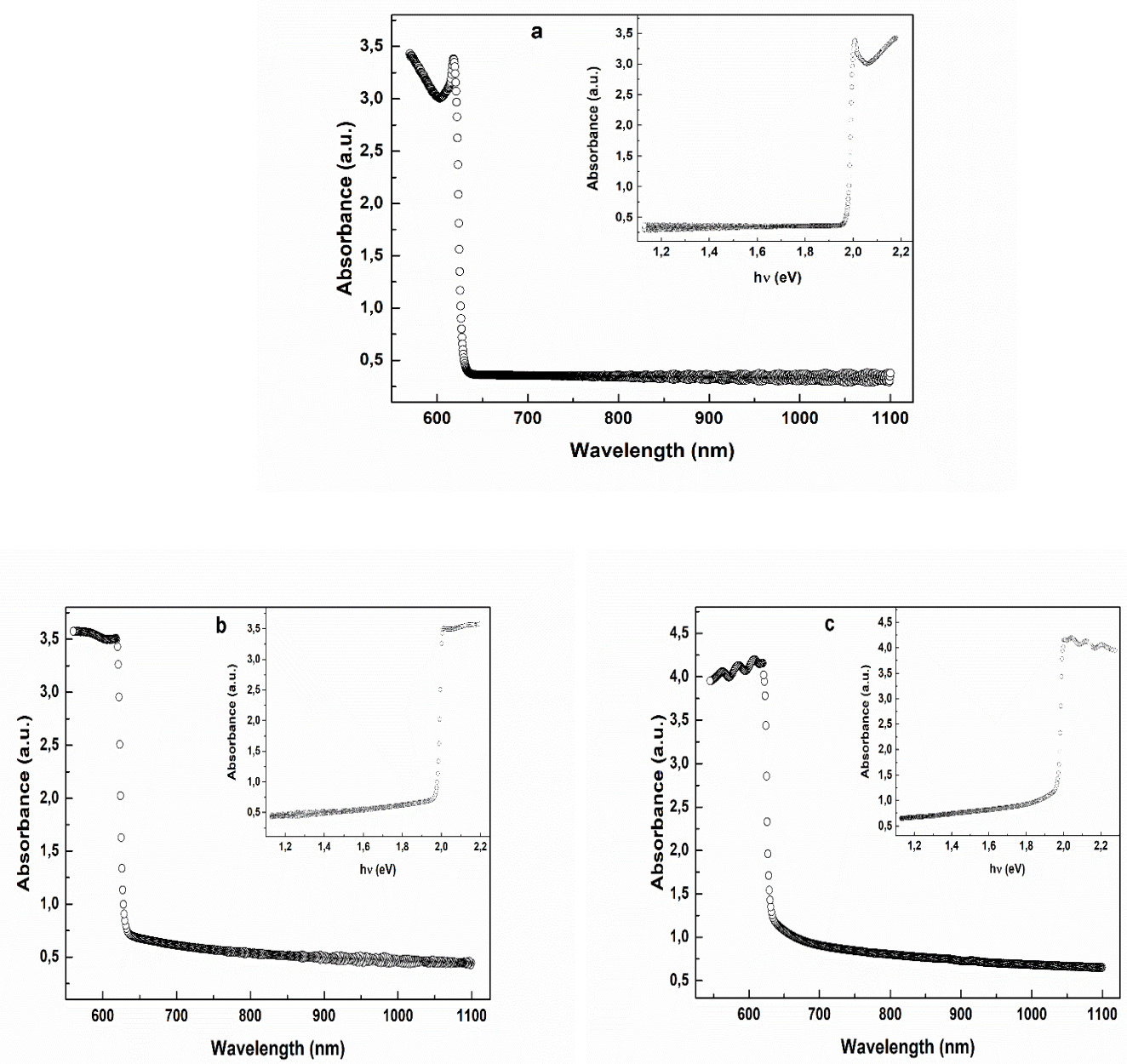

Figure 6. The optical absorption spectra of (a) GaSe single crystal substrate, (b) undoped, (c) boron doped InSe thin films grown on GaSe single crystal substrates.

From the absorption spectra of the GaSe single crystal, it is seen that a sharp increasing is observed at $2.01 \mathrm{eV}$ wavelength, which is attributed to optical absorption of free excitons. Similar peaks are also observed in the absorption spectra of undoped and boron doped InSe thin films grown on GaSe single crystal substrates at $2.00 \mathrm{eV}$ and $1.99 \mathrm{eV}$ wavelengths, respectively (Fig. $6 \mathrm{~b}-\mathrm{c}$ ). These decreases at the band gap energy can be attributed to the defect and dopant states absorptions. However, this should be checked with other experiments. Also, Urbach energies of GaSe single crystal substrate, undoped and boron doped InSe thin films grown on GaSe single crystal substrates were calculated to be $14.02 \mathrm{meV}$, $19.98 \mathrm{meV}$ and $32.17 \mathrm{meV}$, respectively. It is seen that calculated Urbach energies of undoped and boron doped InSe thin films grown on glass substrates are found bigger than undoped and boron doped InSe thin films which are grown on GaSe single crystal substrates. 


\section{CONCLUSION}

Undoped and boron doped InSe thin films were grown on glass and GaSe single crystal substrates by SILAR technique. The structural, morphological and optical properties of these thin films were studied by using XRD, AFM and UV-Vis measurements. The structure of the InSe thin films grown on glass substrates were hexagonal with P61 space group while the InSe thin films grown on GaSe single crystal substrates were hexagonal with P63/mmc space group. The average particle sizes of InSe thin films grown on glass and GaSe single crystal substrates were found between 26.5-60.2 nm and 30.9-101.5 nm, respectively. The optical absorption spectra of InSe thin films grown on both glass and GaSe single crystal substrates showed absorption maxima around 2.00 and $2.24 \mathrm{eV}$, respectively. Here we demonstrated that at the thin film deposition processes the used substrate types effect the structures and other physical properties of thin films.

\section{REFERENCES}

[1] Ertap H., Karabulut M., Structural and electrical properties of boron doped InSe single crystals, Materials Research Express, 6 (2019) 035901.

[2] Duman S., Gürbulak B., Doğan S., Türüt A., Electrical characteristics and inhomogeneous barrier analysis of Au-Be/p-InSe: Cd Schottky barrier diodes, Microelectronic Engineering, 86 (2009) 106110.

[3] De Blasi C., Micocci G., Mongelli S., Tepore A., Large InSe single crystals grown from stoichiometric and non-stoichiometric melts, Journal of Crystal Growth, 57-3 (1982) 482-486.

[4] Savchyn V. P., Kytsai V. B., Photoelectric properties of heterostructures based on thermo-oxidated GaSe and InSe crystals, Thin Solid Films, 361 (2000) 123-125.

[5] Kobbi B., Kesri N., Physico-chemical and electrical properties of InSe films, Vacuum, 75 (2004) 177-182.

[6] Ertap H., Mamedov G. M., Karabulut M., Bacioglu A., Pool-Frenkel thermoelectric modulation of exciton photoluminescence in GaSe crystals, Journal of Luminescence, 13 (2011) 1376-1379.

[7] Yüksek M., Ertap H., Elmali A., Yaglioglu H. G., Mamedov G. M., Karabulut M., Özturk M. K., Two photon absorption characteristics of bulk GaTe crystal, Optics\& Laser Technology, 44 (2012) 2178-2181.

[8] Gamal G. A., Azad M. I., Photoelectric studies of gallium monosulfide single crystals Journal of Phys. Chem. Solids, 66 (2005) 5-10.

[9] Ertap H., Bacıoğlu A., Karabulut M., Photoluminescence properties of boron doped InSe single crystals, Journal of Luminescence, 167 (2015) 227-232.

[10] Cuculescu E., Evtodiev I., Caraman I., Leontie L., Nedeff V., Rusu D., Transport and generationrecombination mechanisms of nonequilibrium charge carriers in $\mathrm{ZnO} / \mathrm{In}_{2} \mathrm{O}_{3} / \mathrm{InSe}: \mathrm{Cd}$ heterojunctions, Thin Solid Films, 519 (2011) 7356-7359.

[11] Segura A., Chevy A., Guedson J. P., Besson J. M., Photovoltaic efficiency of InSe solar cells, Solar Energy Materials, 2 (1979) 159-165.

[12] Pathan H. M., Kulkarni S. S., Mane R. S., Lokhande C. D., Preparation and characterization of indium selenide thin films from a chemical route, Materials Chemistry and Physics, 93 (2005) 1620.

[13] Yüksek M., Nonlinear refraction effects of amorphous semiconductor InSe thin films according to film thicknesses and/or pulse durations, Optic Communications, 285 (2012) 5472-5474. 
[14] Sen S. S., Biswas N. N., Khan K. A., Temperature effect on the electrical and optical properties of indium-selenide thin-films, Applied Energy, 65 (2000) 51-58.

[15] Gopal S., Viswanathan C., Karunagaran B., Narayandass S. K., Mangalaraj D., Yi J., Preparation and characterization of electrodeposited indium selenide thin films, Crystal Research Technology, 40 (2005) 557-562.

[16] Matheswaran P., Kumar R. S., Sathyamoorthy R., Effect of annealing on the structural and optical properties of InSe bilayer thin films, Vacuum, 85 (2011) 820-826.

[17] Chen X., Hou X., Cao X., Ding X., Chen L., Zhao G., Wang X., Gallium sulfide thin film grown on GaAs (1 0 0) by microwave glow discharge, J. Cryst. Growth, 173 (1997) 51-56.

[18] Suh S., Hoffman D. M., Chemical vapor deposition of gallium sulfide thin films, Chemistry of Materials, 12 (2000) 2794-2797.

[19] Sanz C., Guillen C., Gutierrez M. T., Influence of the synthesis conditions on gallium sulfide thin films prepared by modulated flux deposition, J. Phys. D: Appl. Phys., 42 (2009) 085108.

[20] Guseinov G. D., Ramazanzade A. M., Visualization of dislocations on basal planes of GaSe single crystals, Phys. Stat. Sol. (b), 23 (1967) 461-465.

[21] Mamedov G. M., Karabulut M., Ertap H., Kodolbaş O., Öktü Ö., Bac1oğlu A., Exciton photoluminescence, photoconductivity and absorption in $\mathrm{GaSe}_{0.9} \mathrm{Te}_{0.1}$ alloy crystals, Journal of Luminescence, 129 (2009) 226-230.

[22] Mane R. S., Sankapal B. R., Lokhande C. D., A chemical method for the deposition of Bi2S3 thin films from a non-aqueous bath, Thin Solid Films, 359 (2000) 136-140.

[23] Lutz, H. Private Communication 1989.

[24] Asabe M. R., Chate P. A., Delekar S. D., Garadkar K. M., Mulla I. S., Hankare P. P., Synthesis, characterization of chemically deposited indium selenide thin films at room temperature, Journal of Physics and Chemistry of Solids, 69 (2008) 249-254.

[25] Anis M. K., Nazar F. M., X-ray and electron diffraction analysis of GaSe crystals, J. Mater. Sci. Lett., 2 (1983) 471-474.

[26] Blasi C. De., Manno D., Rizzo A., Study of the polytypism in melt grown InSe single crystals by convergent beam electron diffraction, Journal of Crystal Growth, 100 (1990) 347-353.

[27] Fotsing J., Julien C., Balkanski M., Annealing and doping effects in layered In2Se3 compounds, Material Science and Engineering, B1 (1988) 139-145.

[28] Cenzual K., Gelato L. M., Penzo M., Parthe E., Inorganic structure types with revised space groups. I., Acta Crystallographica Section B: Structural Science, 47 (1991) 433-439.

[29] Urbach F., The long-wavelength edge of photographic sensitivity and of the electronic absorption of solids, Phys. Rev., 92 (1953) 1324.

[30] Mamedov G. M., Karabulut M., Kodolbaş O. A., Öktü Ö., Exciton photoconductivity in Ge-doped GaSe crystals, Phys. Stat. Sol. (b), 242 (2005) 2885-2891.

[31] Ertap H., Baydar T., Yüksek M., Karabulut M., Structural and optical properties of gallium sulfide thin film, Turkish Journal of Physics, 40-3 (2016) 297-303. 